\title{
A GEOGRAPHICAL EXAMINATION ON SOCIO-SPATIAL PROPERTIES OF COFFEEHOUSE CULTURE
}

DOI: http://dx.doi.org/10.18509/GBP.2016.31

UDC: $316.723(560.3 / .8)$

\section{Assoc. Prof. Dr. Ogün COŞKUN}

Atatürk University, Faculty of Education, Department of Geography Education, Turkey.

\begin{abstract}
Coffeehouses are special social places which take place in rooted cultural heritage of Anatolia. Their existence, historical origins, sociological features and also their spatial properties contain various elements which are worth examining. Their rural and urban examples, their structural elements for different requirements and the functional transformation they went through are very interesting. Coffeehouses with their sub-types meeting various needs and the qualities which developed and changed during the long time periods when they became popular have gained an important perspective as a cultural place. The aim of this study is to evaluate the spatial properties of coffeehouses as well as their historical and sociological dimensions. Their modern-day appearance, distribution and the functional transformation process were roughly examined. Accordingly, the aim was to analyze coffeehouses and the culture they formed (coffeehouse culture) with a geographical perspective.
\end{abstract}

Key words: Culture, space, cultural geography, coffeehouse, coffeehouse culture.

\section{INTRODUCTION}

Due to its location, Anatolia has served as a cultural corridor between east and west. Many works of art, institutions, and places surviving from past to present bear traces of east and west and they attract attention because of these qualities. Some of the qualities which make these places draw attention are their historical, cultural, and social features, and the change and transformation they went through in time. One of these interesting places which share these features is coffeehouses.

Increasing number of studies focusing on space in social studies in recent years has led to an interpretation of geographical environment in cultural terms and variety in space [1]. It is without doubt that this rich style of approach will promote the importance of both space and spatial understanding and also geographical view and analysis. In this developing perspective, it will be correct to discuss coffeehouses as one of the places supplementing identity and belonging in rural and urban areas and to evaluate them within the framework of their interaction with the geographical environment.

Due to its deep rooted history, coffeehouses have attracted many local or foreigner historians, men of letters, folklorists and sociologists' attention and become the subject of many research studies. Among these studies, many studies on history which examined Ottoman coffeehouses in Istanbul and were prepared in different formats (book, article, master's thesis, and so on) are quite remarkable [2]. In addition to these historical studies which pay ultimate attention to study the examples from the past with their different aspects, it is understood that today's coffeehouses, however, draw attention of academicians like sociologists and folklorists. Although Turkish geographers have not 
paid a lot of attention to them till now, it seems possible that coffeehouses might become the subject matter of geographical examinations as a socio-cultural place which meets important social needs.

The first examples of coffeehouses were in the Ottoman capital city, Istanbul and they were commercial places where coffee was brewed and served but over the centuries they changed, transformed, and became popular. Moreover, coffeehouses which withstood the test of time and gained function and variety according to the changing social needs became an important part of the interaction between culture and space. Today coffeehouses find a place to themselves in the most important socio-cultural places of rural and urban areas. In one sense, the mentioned sustainability causes coffeehouses to become a social mirror and at the same time carries them to the field of interest of human geography, a human based discipline.

\section{PURPOSE AND METHOD}

The purpose of this study is to examine the coffeehouses, a private social place and the culture they create with a geographical perspective. Historical development of coffeehouses and their present spatial distribution were analysed under different sub-titles in this study which serves the purpose of general evaluation and a short discussion. Considering the analysis, first of all, variety of studies obtained were evaluated with survey method, and then observations and examinations were carried out about different types of in situ coffeehouses. In addition to the interviews carried out with different institutions (Turkish Coffeehouses Federation and Turkish Statistical Institute and so on) for statistical distribution and evaluations, the data obtained from the Confederation of Turkish Tradesmen and Craftsmen were used. Regarding the spatial distribution of coffeehouses, the statistics were interpreted. The study was completed with a discussion on the reviewability of coffeehouses specific to the cultural geography.

\section{HISTORICAL BACKGROUND OF COFFEEHOUSES}

The appearance and development of coffeehouses in Turkey naturally occurred at the same time with its popularity and consumption in the country. Coffee is a tropical plant and the most important and the most famous two coffee species are Arabica Coffee (coffea arabica) and Liberian coffee (coffea liberica). Both of them are native to African continent but it is known that Coffea Arabica, widely consumed in the world, is native to highlands of Ethiopia [3]. Coffee spread from Yemen to Hejaz and Cairo in the first quarter of the $16^{\text {th }}$ century and most probably it reached to Syria with large groups of pilgrims and it came to Istanbul in just ten years, about in 1550s [4].

With its appearance and consumption, the first examples of coffeehouses were introduced to Istanbul during the reign of the Suleyman I in the $16^{\text {th }}$ century. However, this new beverage was questioned by the ulema and sometimes it was banned by the Sheikulislam fatwas. Moreover, this new situation caused a discussion about the existence of the coffeehouses [5]. Coffeehouses were public places where coffee was made and consumed at the beginning of this period. But then, it is known that coffeehouses became places to be distrusted. Despite the valid reasons for this mistrust like coffee being a new beverage and not being able to estimate what type of functions coffeehouses would have, these public places became widespread in a short time. However, during this proliferation period, they received some prohibitions and complaints. Coffeehouses were closed 
sometimes because of political discussions, rumours, and fights between the opponents of government and sometimes because of violating the bans on tobacco and alcoholic drinks or various excuses. While the aforementioned complaints were sometimes very simple subjects like the high volume of the gramophone or noise, there were sometimes serious complaints which caused the coffeehouses to be closed such as gambling, selling and consuming alcoholic beverages and drugs [6].

It was viewed that during the following centuries a traditional Turkish coffeehouse gained the characteristic features which would be called as "Ottoman coffeehouse" in literature. It is possible to state that until the $20^{\text {th }}$ century, coffeehouses gained wide prevalence and then variety with social adaptation. For example, as a result of political and economic developments in the $18^{\text {th }}$ century, it was found that even janissary, a military class, opened and ran coffeehouses, known as "janissary coffeehouse"[7]. Even in the $19^{\text {th }}$ century, it was stated in a study which discussed coffeehouses in Istanbul that the coffeehouses became a centre of communication for Istanbul in that period and for that reason, many spies in search of secret information dwelled in these places [8].

Coffeehouses which appeared in the $16^{\text {th }}$ century and became popular in the $17^{\text {th }}$ and $18^{\text {th }}$ centuries met a lot of different social needs at that time. Moreover, some activities took place in coffeehouses like the Turkish shadow theatre (Karagöz-Hacivat plays), the storyteller, meddah, and light comedy and political satires. In that long period, a large variety of coffeehouses emerged like neighbourhood coffeehouses, minstrel coffeehouses, semai coffeehouses, tradesmen coffeehouses, fire brigade coffeehouses, and meddah coffeehouses [9].

One of the social places which appeared with the transformation which coffeehouses went through was "kiraathane" (reading-houses). The word "k1raathane" derived from the Arabic words "kıraat" meaning reading and "hâne" meaning house and it is a name given to the coffeehouses where there are books, magazines and they are read. It was stated that kiraathane appeared as a result of journalism developing with Tanzimat reforms and the need for reading [10], so it is possible to evaluate them as a result of cultural evolution of coffeehouses due to their didactic format and being a popular place among the Ottoman elites.

One of the most important changes experienced in the coffeehouses was the types of food and beverages consumed in these places from the past to present. In addition to drinking coffee in coffeehouses, lemonade and sherbet were drunk and water pipe was smoked. Moreover, it was determined that snacks like Turkish delight, candies, and jam were consumed there [11]. In the following periods, "tea", the most common hot drink of modern day coffeehouses, began to be served and in the $20^{\text {th }}$ century tea competed with coffee. The most important advantages of tea in this competition are that it is much cheaper and it is grown in the Eastern Black Sea region and it has become widespread in a very short time. Justifying its various reflections in literature, it is also stated that tea has created its own addicts and it has ascended the throne of coffee [12].

As seen, coffeehouses has met different needs of the society since the $16^{\text {th }}$ century and meanwhile, the increasing quantity and popularity have brought variety of products and change in quality and thus, a socio-cultural space which existed till today has appeared.

\section{SPATIAL FEATURES OF COFFEHOUSES}

Nearly 500 year old history of coffeehouses caused modern-day coffeehouses to acquire a cultural heritage form and also they installed them a mission to continue their existence. 
Of course, this long period of time interval has brought with it a lot of changes and firstly, it caused the concept of coffeehouse to be exposed to extension of meaning. Modern-day coffeehouses have changed considering the needs of the society today and they have become socio-cultural places. The first feature which attracts attention with the changing spatial appearance is the functional change and extension of meaning. Today when you say coffee, the places where coffee is made and served does not come to mind. Nowadays, the term coffeehouse is used in such a way to include places which have functions like, teahouse, coffeehouse, and kiraathane. Whichever of these places the person who leaves his house goes to, he says, "I'm going to a coffeehouse" and the term "coffeehouse" is used by the public to include places like teahouse, and kiraathane. In this study, coffeehouse was used as an umbrella term compatible with its use in daily life.

Of course, the only change which appeared about coffeehouses is not extension of meaning. In the meantime, it was observed that the number of coffeehouses increased considerably and they became widespread from Istanbul to other regions of Anatolia. It will be to the point to examine the spatial distribution of modern-day coffeehouses in order to consider the increase in quantity and popularity. ${ }^{1}$ The register records belonging to the Confederation of Turkish Tradesmen and Craftsmen were used as a comprehensive and current source of statistical information. In these records, business organizations like, teahouse, coffeehouse and kiraathane were grouped under two different titles. Coffeehouse, kıraathane and Internet café are discussed in one group while businesses like country coffeehouse, tea garden, teahouse, and picnic and recreation centres are discussed in another group. These two sets of data which were evaluated together due to their content involve business enterprises such as coffeehouse, kiraathane and teahouse. However, it will be correct to evaluate these statistics for providing insights rather than for having precision. It is certain that more detailed and clear statistics belonging to the provinces will be created with field work based on physical site visit and observations. When Table 1 and Figure 1 are examined carefully, it is seen that the first thing that attracts the attention about these businesses is their widespread presence throughout the country. In fact, the existence of mentioned business organizations in 81 provinces more or less can be accepted as a signal for spatial dispersion. The second important feature with these visuals is unequal distribution. Istanbul, at the top of the list, witnesses this intensity because it is the first place where coffeehouses opened, it was the capital city of Ottoman Empire, and today it is the biggest city in Turkey. İzmir, Bursa, Balıkesir, Manisa, Aydın, Ankara, Mersin and the other provinces taking place on the top constitute important population attraction centres in Turkey and in the geographical regions where they are located. These businesses show parallel distribution with the distribution of population and at the same time this refers to the correlation with geographical factors which affect the distribution of population in the country. The population attraction centres which compose the weighted work and employment areas draw attention because they are the areas where businesses like coffeehouse, kıraathane, teahouse offering services are densely located (Table 1-Figure 1).

${ }^{1}$ Different statistical data were encountered in different sources about the number of coffeehouses. For example, it was stated by the authorities from the Turkish Coffeehouses Federation that they had 85.000 members throughout the country in the year 2016. According to the annual business statistics published by Turkish Statistical Institute, there were total 120.367 business organizations which gave "beverage services" across the country in 2014. 
Table 1. The distribution of business enterprises which offer services like coffeehouse, kiraathane, teahouse, and so on in Turkey (15.02.2016).

\begin{tabular}{l|llll} 
Province & Number & Province & Number \\
\hline İstanbul & $\mathbf{7 . 6 5 1}$ & Kocaeli & 1.854 \\
\hline İzmir & 6.560 & Edirne & 1.853 \\
\hline Bursa & 4.822 & Muğla & 1.818 \\
\hline Balıkesir & 3.754 & Trabzon & 1.657 \\
\hline Manisa & 3.685 & Zonguldak & 1.428 \\
\hline Aydın & 2.969 & Kurklareli & 1.391 \\
\hline Ankara & 2.715 & Ordu & 1.340 \\
\hline Mersin & 2.702 & Gaziantep & 1.263 \\
\hline Tekirdağ & 2.341 & Hatay & 1.239 \\
\hline Antalya & 2.304 & Afyonkarahisar & 1.152 \\
\hline Konya & 2.187 & Eskişehir & 1.094 \\
\hline Denizli & 2.067 & Kütahya & 1.089 \\
\hline Samsun & 1.951 & Diyarbakır & 1.087 \\
\hline Çanakkale & 1.945 & Malatya & 1.031 \\
\hline Adana & 1.893 & Other provinces & 25.170 \\
\hline Sakarya & 1.858 & Total & $\mathbf{9 5 . 8 7 0}$ \\
\hline \multicolumn{1}{c}{ Sour } & & \\
\hline
\end{tabular}

Source: It was compiled from the records of the Confederation of Turkish Tradesmen and Craftsmen (This data involves the businesses like coffeehouse, kiraathane, Internet café, country coffeehouses, tea garden and picnic and recreation centres).

Differentiation can be stated as another spatial feature which is as important as distribution. The most remarkable spatial differentiation and distinction about coffeehouses are on the rural and urban examples. While "village coffeehouses" make up the most distinct example in rural areas, neighbourhood or district coffeehouses compose the most common examples in urban areas. Of course, apart from these two popular examples; it is possible to mention other types of coffeehouses. Early riser coffeehouses, minstrel coffeehouses, kuraathanes, country coffeehouses, labour and worker coffeehouses, fellow countrymen coffeehouses, and coffeehouses called by the public as "coffeehouses with games" where different card games are played can be counted as the types of coffeehouses which come to mind. These examples of coffeehouses are very important as each of them can be a research topic and also they display the spatial diversity created by the modern day coffeehouses. Moreover, each type of coffeehouse can meet different social needs.

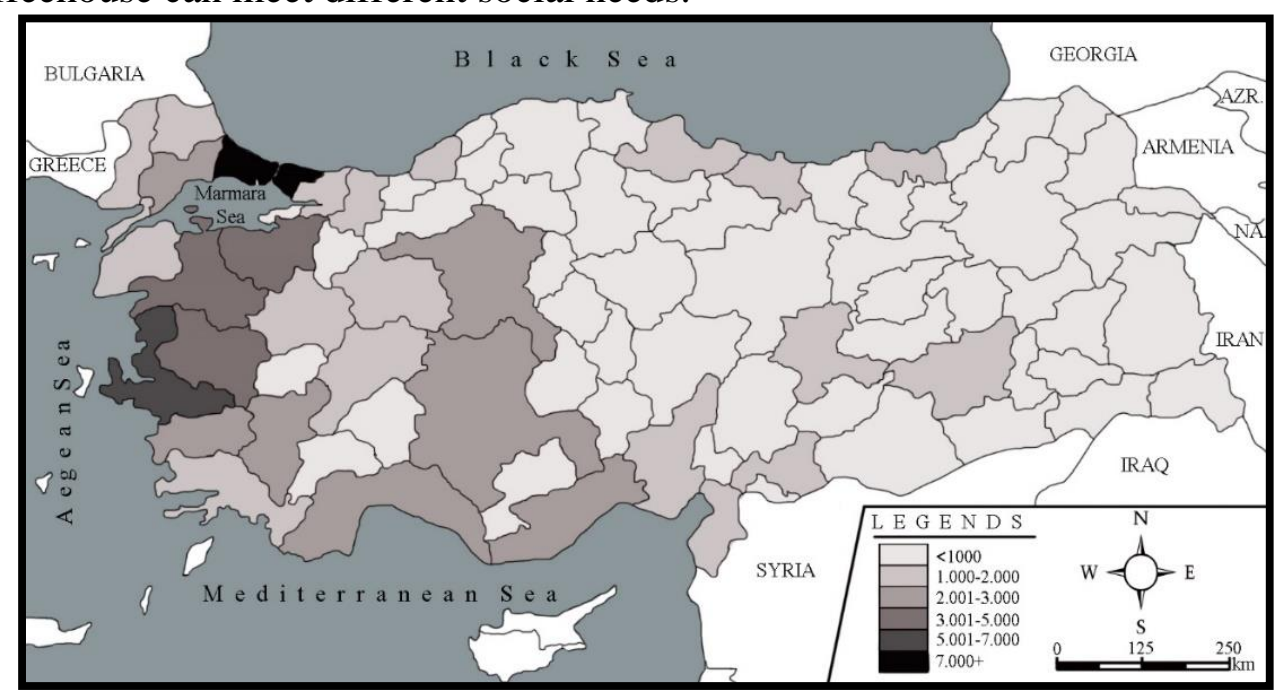

Figure 1. The distribution of business enterprises which offer services like coffeehouse, kiraathane, teahouse, and so on in Turkey (15.02.2016). 
Another remarkable feature about the coffeehouses is that their physical qualities are compatible with the geographical environment. Especially the climate conditions of the regions where these coffeehouses are located determine the rate of indoor or outdoor places in coffeehouses. In the coastal regions with mild climate conditions, coffeehouses use outdoor more whereas it is possible to observe in the interior regions with continental climate conditions that the rate of enclosed space is higher. Naturally, more in-depth evaluations related to this and similar correlations might be possible with field work.

\section{DISCUSSION AND RESULTS}

Coffeehouses today compete with their European similars like café or cafeteria or global coffee chains like Starbucks or Gloria Jean's or hybrid examples like the Internet café. This competition causes traditional coffeehouses to make changes. Today a teenager going to a coffeehouse asks for a password for wi-fi (wireless fidelity) before ordering his drink or it is really difficult to distinguish coffeehouses which broadcast football matches on large screens during the football league season from the stadiums. All these things and more than this can be accepted as a reflection of change the coffeehouses went through in time. However, no matter at what level this change occurs, it is viewed that coffeehouses still maintain their existence as a socio-cultural place. From these aspects, today coffeehouses are special social places which can contain within itself society's existing qualities and some cultural elements coming from the past. As stated in the introduction, these features as well as other qualities make coffeehouses become field of interest for human geography that deals with the people and also they make coffeehouses a great place for the research studies of cultural geography. There are important correlations between spatial distribution of coffeehouses and geographical factors such as location, climate, population, migration, and economic activities. In-depth evaluation of the aforementioned correlations will be possible with applied geographical examinations based on in situ observations. Coffeehouses are an important research topic for research fields like urban geography, rural geographical studies or historical geography. Moreover, in our opinion, they are available places for cultural geography studies. Coffeehouses, one of the places which reflect the Turkish identity best, exhibit physical diversity and they are shaped in line with social needs. It is regarded that they have a quality which is supplementary and enhancing the sense of belonging in rural and urban places, so they are effective on identity with these aspects. Coffeehouses have a special position regarding the culture-place interaction and within the framework of all these aspects, they are the places which will be exposed to in-depth examination with a perspective of cultural geography. They are like a laboratory for collecting data for the subjects like culture-place interaction and identity-place relation. In parallel with the increasing number of the studies to be carried out in time, opportunities will be provided to compare the Anatolian examples and different examples. Thus, it can be anticipated that cultural diffusion and the borders of cultural region will be examined with analytical studies. What we expect from this short paper is that it attains its purpose by drawing the attention of Turkish Geographers on the subject and thus increasing the number of geographical studies on coffeehouses. Therefore, the continuity of living heritage will be ensured and also more in-depth analysis about the spatial distribution of coffeehouses and their interaction with geographical environment will be performed. 


\section{REFERENCES}

[1] Short, J.R. (2015). Human geography: a short introduction. New York, NY: Oxford University Press. pp: 100-105.

[2] See: Yaşar, A. (2005). Osmanlı şehir mekânlar1: kahvehane literatürü. Türkiye Araştırmaları Literatür Dergisi, 3 (6), 237-256.

[3] Doğanay, H., ve Coşkun, O. (2012). Tarım coğrafyası. Pegem Akademi Yayıncılık, (İkinci Bask1), Ankara. s: 238-240.

[4] Hattox, R.S. (1998). Kahve ve kahvehaneler: bir toplumsal içeceğin Yakındoğu'daki kökenleri. (İkinci Baskı). İstanbul: Tarih Vakfı Yurt Yayınları. s: 24.

[5] Saraçgil, A. (1999). Kahve'nin İstanbul'a girişi (16. ve 17. yüzyıllar). (Ed: Héléne Desmet-Grégoire, François Georgeon), Doğu'da kahve ve kahvehaneler içinde (ss: 2741). İstanbul: Yap1 Kredi Yayınları. s: 27-33.

[6] Akbulut, U. (2015). Tanzimat ve Meşrutiyet dönemlerinde kahvehanelerden kaynaklanan sosyal sorunlara dair bazı tespitler. Atatürk Üniversitesi Türkiyat Araştırmaları Enstitüsü Dergisi (TAED), 54, 561-583.

[7] Çaksu, A. (2011). On sekizinci yüzyıl sonu İstanbul yeniçeri kahvehaneleri. (Derleyen: Dana Sajdi). Osmanlı laleleri, Osmanlı kahvehaneleri: on sekizinci yüzyılda hayat tarzl ve boş vakit eğlenceleri içinde (ss: 151-173). İstanbul: Koç Üniversitesi Yayınları. s: 171.

[8] Kırlı, C. (2010). Kahvehaneler: 19. yüzyıl Osmanlı İmparatorluğu'nda kamuoyu. (Ed: Ahmet Yaşar), Osmanlı kahvehaneleri: mekân, sosyalleşme, iktidar içinde (ss: 99-122). 2. Bask1, İstanbul: Kitap Yayınevi. s: 102.

[9] Sökmen, C. (2011). Aydınların iletişim ortamı olarak eski İstanbul kahvehaneleri. İstanbul: Ötüken Yayıncılık. s: 40-56.

[10] Kuzucu, K. (2012). Kahvehaneden kıraathaneye geçiş ve ilk kıraathaneler. (Ed: Emine Gürsoy Naskali), Türk Kahvesi Kitabı içinde (ss: 161-208). 2. Bask1, İstanbul: Kitabevi Yayınları. s: 161.

[11] Georgeon, F. (1999). Osmanlı İmparatorluğu'nun son döneminde İstanbul kahvehaneleri. (Ed: Héléne Desmet-Grégoire, François Georgeon) Doğu'da Kahve ve Kahvehaneler içinde (ss: 43-85). İstanbul: Yapı Kredi Yayınları. s: 47-48.

[12] Ayvazoğlu, B. (2012). Kahveniz nasil olsun? Türk kahvesinin kültür tarihi. (İkinci Bask1). İstanbul: Kap1 Yayınları. s: 187. 